\title{
The Signs of the Differences in the Weights of the Ministers in Hungary between 1848 and 1944
}

\author{
Gábor Bathó \\ Pázmány Péter Catholic University \\ gabor.batho1@gmail.com
}

\section{Doi:10.5901/ajis.2016.v5n3s1p48}

\begin{abstract}
The formal weight of the individual ministers in the cabinet or at the cabinet council is regulated in acts or at least one act. In the parliamentary form of government, and in the chancellor and council type of government, the ministers have to have the same weight. For this reason - according to my view - not only the formal, legal regulations have to be checked, but the daily operation of the cabinet as well. In my opinion the following circumstances should be examined: prime minister's portfolio, ministers having more portfolios at a time, size of the cabinet, permanent and temporary substitutes of the prime minister and the ministers, length of the time spent in the cabinet, length of the time having the same portfolio, speaking order at the cabinet council and communication with the head of state. It also may be important to evaluate the factor being a relative to the prime minister or other ministers. The building of the ministry is a circumstance also to be checked to find out the weight of the minister.This paper examines the weight of the individual ministers in the cabinet by analyzing the previous conditions. The main sources for the analysis are the minutes of the cabinet council between 1848 and 1944.
\end{abstract}

Keywords: legal history, Hungarian government, ministerial structure, power relations in the cabinet

\section{Weight of the Ministers in the Government}

The form of government and the type of government define - among others of course - the relationship of the ministers within the cabinet. The determination of the form of government in a specific country, gives us a comprehensive picture on the structure of that state and the operation of the main state organs. The form of government gives answers mainly to the following two questions: What is the relationship between the legislative and the executive power? Who exercises the executive power? Regarding the relationship of the legislative and executive power the decisive circumstance is the extent of control by the parliament, the legislative power on the government, the executive power. ${ }^{1}$ The other circumstance to determine the form of government is the answer to the question: by whom is the executive power exercised. ${ }^{2}$

The form of government and the type of government are two concepts that are frequently mixed up sometimes even in the scientific literature as well. I agree - accepting others opinions - that these two concepts are different from each other. The form of government shows the relationship between the legislative power branch and the executive power branch within a state. Meanwhile the type of government shows the role of the prime minister in the government, the prime minister's position in the ministers' council. There are some governmental models in which this distinction can be recognised; the justness of this distinction can be accepted. We can find different types of government in the same form of government; this confirms the differentiation of the two concepts: the form of government and the type of government. For instance, today's United Kingdom and Germany both have a parliamentary form of government, but their type of government is different from each other. Therefore, the form of government and the type of government vary from each other. ${ }^{3}$

The form of government is surely determined by legal acts, and what is more, the form of government is usually determined by the highest legal norm available in the country. The form of government has an equal significance to the form of state that is why it must be regulated in the highest available legal norm: a constitution or a legal norm in the place of the constitution. The type of government

\footnotetext{
1 Péteri, Zoltán: Az államok rendszerezése: államtípusok és államformák. In: Takács, Péter: Államelmélet. Bíbor, Miskolc, 1997. 108. p.

2 Duverger, Maurice: Állam és kormányzat. In: Takács, Péter (ed.): Államtan. Szent István Társulat, Budapest, 2003. 387-389. p.

3 Szalai, András: Kormánytípus Magyarországon avagy a Sartori modell felülvizsgálata. In: Kodifikáció és közigazgatás. 2014/1. 42. p. 
As I examined the practice, the main sources for this paper are the minutes of the cabinet council between 1848 and 1944 to be found in the Hungarian National Archives (Magyar Nemzeti Levéltár - MNL). I have read and examined these minutes in a fully comprehensive manner.

There can be many circumstances, which could be examined to find out the power relations in a government, in a specific ministers' council. Such circumstances may be the prime minister's portfolio, ministers having more portfolios at a time, size of the cabinet, permanent and temporary substitutes of the prime minister and the ministers, length of the time spent in the cabinet, length of the time having the same portfolio, speaking order at the cabinet council and communication with the head of state. It also may be important to evaluate the factor being a relative to the prime minister or other ministers. The building of the ministry is a circumstance that is also to be checked to find out the weight of the minister. To show the differences of the nature of the previously mentioned circumstances, I have chosen four of them for the purpose of this paper: multiple portfolios, the prime minister's substitutes and the question of the ministry buildings.

\section{Multiple Portfolios}

Regarding the multiple portfolios, my first task was to check the purpose of this phenomenon. The archetype of the Hungarian governmental structure was defined in $1848 .{ }^{4}$ Its 10 . $\S$ stated that the ministers' council consists of a president and - if the president does not have a portfolio - apart from the president eight ministers. This regulation was clear; the first government had to have nine members. Above this, there was an additional indication in this article: "if the president does not have a portfolio." It means that having multiple portfolios is not forbidden regarding the will of the legislator especially for the prime minister (president of the ministers' council in this context).

The practice supports the above. It was usual for the prime ministers to have a portfolio besides being prime minister in the examined period. The very first prime minister to have a portfolio was the very first responsible prim minister of Hungary, Lajos Batthyány. For practical purposes he was the leader of the ministry of war temporarily. Furthermore, he was the only prime minister to be a leader of seven ministries; ha had seven portfolios for a two weeks period during the Hungarian revolution of 1848. Between $12^{\text {th }}$ and $28^{\text {th }}$ October 1848 he was the leader of all ministries having their seats in Budapest, except for the ministry of war. ${ }^{5}$ In the case of the first ministers' council it was a necessity for the prime minister to have portfolios as well. It was just temporary and extraordinary.

The first government that was properly organised according to the $10 \S$ of Act No III of 1848 was the government of István Bittó. This government operated between March 1874 and March 1875. During this one year the prime minister acted only as a prime minister, all the other ministries were lead by one minister, and there were no ministers with multiple portfolios. ${ }^{6}$

Later it became habitual for the prime minister to have portfolios during their whole service. This phenomenon was not induced by necessity; it was not temporary, nor extraordinary. Sándor Wekerle was finance minister from 1889 in two consecutive governments. When he became prime minister in 1892, he kept his portfolio, and remained finance minister during his time as prime minister until 1895. Kálmán Széll was the first prime minister to have two portfolios at a time. He was minister for the interior during his whole time as prime minister, but he lead the quasi foreign ministry ${ }^{7}$ for a short time as well. The previously mentioned Sándor Wekerle was the first prime minister who had three portfolios besides being a prime minister. He was finance minister, minister of war and the minister for the Croatian affairs for a short time. ${ }^{8}$ It was very usual for the prime ministers to keep their former portfolio when they were appointed prime minister.

I would like to consult very briefly the question of being a professional or a politician regarding the ministers. This topic is worth a complete paper, but this time I would like only to raise the question, and suggest an answer for that. The ministers', the government members' professional and political attributes seem to be inseparable from each other. The professional carriers (e.g. in-ministry pre-life, being secretary of state) and the political positions (e. g. party leadership) are interlaced in the lifespan of a person. The prime ministers of course usually chose their ministers to fit into their political views. It is easier for the minister, if he had experiences in the central public administration. ${ }^{9}$ It must be stated

\footnotetext{
${ }^{4}$ Act No. III of 1848 on the independant and responsible Hungarian government

${ }^{5}$ Bölöny, József: Magyarország kormányai 1848-1987.Budapest, Akadémiai, 1987. 81. p.

${ }^{6}$ Bölöny, József: Magyarország kormányai 1848-1987.Budapest, Akadémiai, 1987. 84. p.

7 The proper name of this ministry is the ministry around the king's person. It was responsible for the connection and the affairs between the emperor and Hungary. From the early it was called quasi foreign ministry.

${ }^{8}$ Bölöny, József: Magyarország kormányai 1848-1987.Budapest, Akadémiai, 1987. 84-87. pp.

9 Ilonszki, Gabriella (ed.): Szakértők és pártemberek. Kormányzati elit Magyarországon 1848-2010. Budapest, Akadémiai, 2011. 45. p.
} 
that the governments are at the same time political-representative and governmental-administrative organs. ${ }^{10}$ This statement is connected with many things. At first it is connected with the nature of the political system, secondly it is connected with the tasks expected from the government (e.g. political direction or bureaucratic management). ${ }^{11}$

As an example Béla Orczy lead four different portfolios in the government of Kálmán Tisza between 1879 and 1890. He was the quasi foreign minister for eleven years, and he was the minister of war in 1882 and 1884, the minister for public labour and traffic in 1886, and minister for the interior in 1887-1889.12 He served in the revolution as a soldier, he had two doctorates, and he worked as an attorney at law. After his service as minister he remained an appreciated politician, and an honoured aristocrat. His carrier in the government shows, that choosing him was a political decision. Of course he was not expert in all war affairs, public labour, traffic and interior affairs.

\section{Prime Minister's Substitution}

I think, that the prime ministers' substitution is an important and an indicator question. Being a substitute to the prime minister is an obvious expression of the prime ministers reliance and dependence, and at the same time it shows the weight of the person in the government.

In the examined period there were two types of substitutes, and both were just temporary. There was no permanent substitute to the prime minister. The first type of temporary substitutes were officially accepted by the head of state (the king or the governor). They were appointed when there was an anticipated or planned absence of the prime minister. Such absences were when the prime minister travelled abroad for more days, or the prime minister needed planned medical attendance. The second type of substitutes were the ones who were not accepted by the heads of state, but only occasionally substituted the prime minister. There were asked by the prime minister to do so.

Already the first government shows substitutes of the prime minister. In April 1848 the minister for traffic and public labour was appointed by the ministers' council (after the initiative of the prime minister) to be the prime minister's substitute while he left Budapest, and travelled to Innsbruck. In July 1848 the minister for religion and education was the substitute of the prime minister during his stay in Vienna. ${ }^{13}$ As this period was to short, no pattern can be shown from these substitutions.

In the government of Gyula Andrássy, he was substituted by the minister for religion and education when he accompanied the king to his journey for two months. ${ }^{14}$ This seems to be a first type of substitution. There were examples for the second type of substitution as well. In January 1869 the minister for the interior lead the ministers' council without any prior document. 15

Let me show two examples for the two types of substitutes in medical cases. On $31^{\text {st }}$ August 1920 it was not the prime minister who presided at the ministers' council, but the minister for commerce. The governor (the head of state) appointed the minister for commerce to substitute the prime minister during his illness. ${ }^{16}$ This is a first type of substitution. On $19^{\text {th }}$ June 1925 the minister for public wellness and labour announced that the prime minister had a sudden sickness, that is why he decided not to preside at the ministers' council, and ordered, that the minister for public wellness and labour should be his substitute. ${ }^{17}$ This is a second type of substitution, without the prior consent from the head of state.

Under the government of István Bethlen (1921-1931), a pattern can be found in the substitutions of the prime minister. József Vass, minister for public wellness and labour was the usual substitute of the prime minister. József Vass was already a minister when István Bethlen became the prime minister. During the ten years of Bethlen-government he substituted the prime minister ${ }^{18}$ for altogether one and a half years. ${ }^{19}$ Seemingly there was a solid trust between these

10 Cotta, Maurizio: Defining Party and Government. In: Blondel, Jean-Cotta, Maurizio: The Nature of party Government. New York, Palgrave, 2000. 56-95. $p$.

11 Ilonszki, Gabriella (ed.): Szakértők és pártemberek. Kormányzati elit Magyarországon 1848-2010. Budapest, Akadémiai, 2011. 45. p.

12 Bölöny, József: Magyarország kormányai 1848-1987.Budapest, Akadémiai, 1987. 85. p.

${ }^{13}$ Bölöny, József: Magyarország kormányai 1848-1987.Budapest, Akadémiai, 1987. 203. p.

14 Bölöny, József: Magyarország kormányai 1848-1987.Budapest, Akadémiai, 1987. 203. p.

${ }_{15}$ MNL W12 Minutes of the ministers' council (K27) 1867-1944. 4th January 1869.

${ }^{16}$ MNL W12 Minutes of the ministers' council (K27) 1867-1944. 31st August 1920.

17 MNL W12 Minutes of the ministers' council (K27) 1867-1944. 19th June 1925.

${ }^{18}$ Example to be found: MNL W12 Minutes of the ministers' council (K27) 1867-1944. 27th November 1925; MNL W12 Minutes of the ministers' council (K27) 1867-1944. 29th January 1926; MNL W12 Minutes of the ministers' council (K27) 1867-1944. 26th February 
two persons. József Vass ministerial service ended with his death in 1930.

\section{Ministry Buildings}

The question of the ministry buildings appeared first on the ministers' councils in 1867. Of course, that was the starting time of the consolidated governmental work after the compromise between Austria and Hungary. During the revolutionary period, the ministries were operating in buildings that were left by the Austrian governmental organs. There was not enough time to develop to a more sophisticated governmental organisation.

My hypothesis was that there are no nodes in this question, and the opportunity to build or to renovate the ministry building shows the weight and the strength of the minister in the government. To the contrary, when I examined the minutes of the ministers' councils it appeared that there are nodes in this question. The topic of the ministry buildings was on the agenda of the ministers' council in 1867, ${ }^{20}$ in $1889,{ }^{21}$ in $1922-1923^{22}$ and in 1940-1941. ${ }^{23}$

These years show dates that were important in the development of the Hungarian government and governmental structure. 1867 is the year when the Austrian-Hungarian Monarchy was created; that is the beginning of the build-up of a new governmental structure. A very similar situation appears in 1922-1923, which is at the beginning of the consolidation period after the First World War. That is also a beginning of a very new era, the development of the governmental structure for the independent Hungary. The beginning of the 1940s meant obviously the preparation for the Second World War. Among these four, the most interesting node is at 1889. In this year, a slight reform was introduced in the ministerial structure. The competencies and the names of two ministries were rearranged and changed. This gave the opportunity for the ministers to initiate the building and renovating some of the ministry buildings.

\section{Summary}

As I articulated before many circumstances affect the inner power relations of a government. For the purpose of this paper I have chosen three from these many. The multiple portfolios raise the question on the nature of the minister's position: is it a pure political position, is it a pure professional position or a combination of both? The substitution of the prime minister shows the trust issues within ministers' council. The question of the ministry buildings point out the greatest rearrangement points in the governmental development.

1926; MNL W12 Minutes of the ministers' council (K27) 1867-1944. 12th March 1926; MNL W12 Minutes of the ministers' council (K27) 1867-1944. 27th May 1926.

${ }^{19}$ Bölöny, József: Magyarország kormányai 1848-1987.Budapest, Akadémiai, 1987. 384. p.

20 MNL W12 Minutes of the ministers' council (K27) 1867-1944. $3^{\text {rd }}$ April 1867.

${ }^{21}$ MNL W12 Minutes of the ministers' council (K27) 1867-1944. 3rd May 1889; MNL W12 Minutes of the ministers' council (K27) 18671944. $26^{\text {th }}$ November 1889.

22 MNL W12 Minutes of the ministers' council (K27) 1867-1944. 12 th January 1921; MNL W12 Minutes of the ministers' council (K27) 1867-1944. 9th February 1923; MNL W12 Minutes of the ministers' council (K27) 1867-1944. 18 th August 1922; MNL W12 Minutes of the ministers' council (K27) 1867-1944. 22 ${ }^{\text {nd }}$ September 1922; MNL W12 Minutes of the ministers' council (K27) 1867-1944. 9th March 1923; MNL W12 Minutes of the ministers' council (K27) 1867-1944. 27 th April 1923; MNL W12 Minutes of the ministers' council (K27) 18671944. 22 ${ }^{\text {nd }}$ June 1923; MNL W12 Minutes of the ministers' council (K27) 1867-1944. 16 $6^{\text {th }}$ February 1923; MNL W12 Minutes of the ministers' council (K27) 1867-1944. 9th March 1923; MNL W12 Minutes of the ministers' council (K27) 1867-1944. 25th May 1923;

${ }_{23}$ MNL W12 Minutes of the ministers' council (K27) 1867-1944. 8th October 1941; MNL W12 Minutes of the ministers' council (K27) 1867-1944. 26 th April 1940; MNL W12 Minutes of the ministers' council (K27) 1867-1944. 25th February 1942; MNL W12 Minutes of the ministers' council (K27) 1867-1944. 21st May 1942. 